\title{
QTLs of factors of the metabolic syndrome and echocardiographic phenotypes: the hypertension genetic epidemiology network study
} Aldi T Kraja*1, Pinchia Huang2, Weihong Tang ${ }^{3}$, Steven C Hunt ${ }^{4}$, Kari E North ${ }^{5}$, Cora E Lewis ${ }^{6}$, Richard B Devereux ${ }^{7}$, Giovanni de Simone ${ }^{7,8}$, Donna K Arnett ${ }^{9}$, Treva Rice ${ }^{2}$ and DC Rao ${ }^{2}$

\begin{abstract}
Address: ${ }^{1}$ Division of Statistical Genomics, Washington University School of Medicine, Saint Louis, MO, USA, ${ }^{2}$ Division of Biostatistics, Washington University School of Medicine, Saint Louis, MO, USA, ${ }^{3}$ Division of Epidemiology and Community Health, University of Minnesota, Minneapolis, MN, USA, ${ }^{4}$ Divison of Cardiovascular Genetics, University of Utah School of Medicine, Salt Lake City, Utah, USA, ${ }^{5}$ Department of Epidemiology, University of North Carolina, Chapel Hill, North Carolina, USA, ${ }^{6}$ Department of Medicine, University of Alabama at Birmingham, Birmingham, AL, USA, ${ }^{7}$ Department of Medicine, Weill Cornell Medical College, New York, NY, USA, ${ }^{8}$ Department of Clinical and Experimental Medicine, Federico II University, Naples, Italy and ${ }^{9}$ Department of Epidemiology, University of Alabama at Birmingham, Birmingham, USA

Email: Aldi T Kraja* - aldi@wustl.edu; Pinchia Huang - phuang@wustl.edu; Weihong Tang - tang0097@umn.edu; Steven C Hunt - steve.hunt@utah.edu; Kari E North - kari_north@unc.edu; Cora E Lewis - clewis@dopm.uab.edu; Richard B Devereux - rbdevere@med.cornell.edu; Giovanni de Simone - simogi@unina.it; Donna K Arnett - Arnett@ms.soph.uab.edu; Treva Rice - treva@wubios.wustl.edu; DC Rao - rao@wubios.wustl.edu

* Corresponding author
\end{abstract}

Published: 27 November 2008

BMC Medical Genetics 2008, 9:103 doi:10.1186/147I-2350-9-103
Received: 28 April 2008

Accepted: 27 November 2008

This article is available from: http://www.biomedcentral.com/I47I-2350/9//03

(C) 2008 Kraja et al; licensee BioMed Central Ltd.

This is an Open Access article distributed under the terms of the Creative Commons Attribution License (http://creativecommons.org/licenses/by/2.0), which permits unrestricted use, distribution, and reproduction in any medium, provided the original work is properly cited.

\begin{abstract}
Background: In a previous study of the Hypertension Genetic Epidemiology Network (HyperGEN) we have shown that metabolic syndrome (MetS) risk factors were moderately and significantly associated with echocardiographic (ECHO) left ventricular (LV) phenotypes.

Methods: The study included I,393 African Americans and I,I33 whites, stratified by type 2 diabetes mellitus (DM) status. Heritabilities of seven factor scores based on the analysis of 15 traits were sufficiently high to pursue QTL discovery in this follow-up study.

Results: Three of the QTLs discovered relate to combined MetS-ECHO factors of "blood pressure (BP)LV wall thickness" on chromosome 3 at $225 \mathrm{cM}$ with a $2.8 \mathrm{LOD}$ score, on chromosome 20 at $2.1 \mathrm{cM}$ with a 2.6 LOD score; and for "LV wall thickness" factor on chromosome 16 at II 3.5 with a 2.6 LOD score in whites. The remaining QTLs include one for a "body mass index-insulin (BMI-INS)" factor with a LOD score of 3.9 on chromosome 2 located at $64.8 \mathrm{cM}$; one for the same factor on chromosome 12 at 91.4 CM with a 3.3 LOD score; one for a "BP" factor on chromosome 19 located at $67.8 \mathrm{cM}$ with a 3.0 LOD score. A suggestive linkage was also found for "Lipids-INS" with a 2.7 LOD score located on chromosome II at II3.I cM in African Americans. Of the above QTLs, the one on chromosome 12 for "BMI-INS" is replicated in both ethnicities, (with highest LOD scores in African Americans). In addition, the QTL for "LV wall thickness" on chromosome 16q24.2-q24.3 reached its local maximum LOD score at marker DI6S402, which is positioned within the 5th intron of the cadherin 13 gene, implicated in heart and vascular remodeling.
\end{abstract}

Conclusion: Our previous study and this follow-up suggest gene loci for some crucial MetS and cardiac geometry risk factors that contribute to the risk of developing heart disease. 


\section{Background}

Metabolic Syndrome (MetS), a cluster of obesity, insulin resistance and glucose intolerance, dyslipidemia, and high blood pressure, is related to echocardiographic (ECHO) measurements of the heart. For example, left ventricular hypertrophy $(\mathrm{LVH})$ is a complex trait that is a major manifestation of target organ damage in hypertension [1]. MetS and LVH are reported to increase the risk of cardiovascular (CV) disease [2-6]. In a recent study we further explored the relationships among these traits by utilizing multivariate factor analysis (FA). Correlations among 15 metabolic and echocardiographic traits analyzed showed significant relationships among MetS risk factors (especially systolic and diastolic blood pressure (BP) and body mass index (BMI)) and cardiac phenotypes. Factors identified represented new combined MetSECHO domains as for example "BP-LV geometry," and "BP-LV wall thickness," and also represented known domains in the MetS such as "BMI-INS," "Lipids-INS," "BP," and ECHO domains "LV wall thickness," and "LV geometry." Quantitative trait loci (QTLs) discovery was warranted based on the heritability estimates reported [7].

Until recently, different studies have reported QTLs for MetS or ECHO. Teran-Garcia and Bouchard [8] provide a comprehensive review of QTLs associated with MetS. In one of their cited studies, Kraja et al [9] studied QTLs for MetS factors in the HyperGEN study for two ethnicities. A QTL with logarithm of odds (LOD) score of 2.8 on chromosome 13p12 for the obesity-INS factor and one with a LOD of 2.6 on chromosome 11q24 for the lipids-INS factor were described for African Americans. Also, QTLs for the BP factor (LOD of 3.2 on chromosome 15q15), for the lipids-INS factor (a LOD of 3.08 on chromosome 8p23), and for the obesity-INS factor (LOD of 3.1 on chromosome 3p26) were reported in whites. More recently both linkage and association analysis of ECHO traits have been reported in the HyperGEN study. Arnett et al [10] studying the LV contractility, reported a LOD of 3.9 at $54 \mathrm{cM}$ on chromosome 11 in African Americans and a 2.8 LOD score at $17.9 \mathrm{cM}$ on chromosome 22. Tang et al [11] reported QTLs for LV early diastolic peak E velocity on chromosome 5 at $133.6 \mathrm{cM}$ with a LOD of 3.6 in African Americans, and a LOD score of 2 on chromosome 12 at 105-109 cM for peak A velocity in whites. In the third paper, Bella et al [12] studied linkage for valve calcification finding LOD scores of 3.2 and 2.6 respectively at 105.6 and $130.4 \mathrm{cM}$ on chromosome 16, and a LOD of 2.9 at $48 \mathrm{cM}$ of chromosome 19.

Another recent publication of Mayosi et al [13] performed genome wide linkage analysis on LV mass of 826 subjects of British families ascertained for high BP, by selecting the proband from the top $5 \%$ of the population distribution.
They obtained moderate LOD scores (1.5-2.67) for electrocardiographic and echocardiographic LV mass.

The present study extends previous investigations by focusing concurrently on both MetS risk components and ECHO phenotypes. In addition, we expect an increase in power for QTL discovery by utilizing FA factors, because they capture inter-variable correlations. In this study we aimed to identify QTLs that control genetic variability of combined MetS-ECHO factors, as well as individual MetS and ECHO factor domains in the Hypertension Genetic Epidemiology Network Study (HyperGEN).

\section{Methods Subjects}

HyperGEN is part of the NHLBI Family Blood Pressure Program (FBPP), which studies the genetic aspects of high blood pressure and related conditions [14]. Further details for the HyperGEN study are provided elsewhere $[7,9-12]$. In the current study the focus was on the siblings and the offspring of the sampled populations. Subjects with less than 8 hours of fasting time, or missing values for any of the 15 traits studied were excluded from the analysis. Consequently, in our study the phenotypes of 1,393 African Americans and of 1,133 Caucasians were analyzed. The samples were organized also by including/ excluding diabetes mellitus (DM) subjects (for more details see Huang et al [7]). Clinical data, echocardiographic measurements, questionnaires, and blood samples were collected with informed consent from the participants.

\section{Echocardiography}

Echocardiograms followed standard protocols as described by Devereux and Roman [15] to obtain twodimensional (2D) guided M-mode, 2D and Doppler measurements. The measurements were first made by sonographers or physicians centrally trained at the Reading Center in New York and subsequently verified or changed by highly experienced cardiologists in the Reading Center, who were blinded to clinical data.

\section{Phenotypic Data}

The 15 traits that follow constitute the original traits which through multivariate factor analyses were transformed into factor scores. The factor scores served as phenotypes in our linkage analyses. Fasting glucose (GLUC) and insulin (INS); triglycerides (TG) and high-density lipoprotein cholesterol (HDLC); body mass index (BMI); medication-adjusted systolic and diastolic blood pressure (SBP and DBP); heart rate (HR), diastolic LV internal dimension (LVID), posterior wall thickness (PWT) and relative wall thickness (RWT); LV mass indexed to height 2.7 (LVMI), aortic root diameter (ARD), arterial stiffness defined by pulse pressure/stroke volume (PP/SV), 
and LV midwall shortening (MWS) underwent appropriate distribution transformations and removal of only a few outliers to achieve normality. Log transformation was applied to INS, HDLC, TG, BMI, RWT, LVMI, PWT, and $\mathrm{PP} / \mathrm{SV}$; the reciprocal of squared GLUC $\left(1 / \mathrm{GLUC}^{2}\right)$ and cubic power transformation for MWS (MWS ${ }^{3}$ ) were applied in both African Americans and whites (see Huang et al. [7] for details). The SBP and DBP of subjects receiving anti-hypertensive medication were adjusted for the anti-hypertensive medication(s) following the method described by Wu et al. [16] and applied in the HyperGEN study to estimate untreated BP levels for various classes of medications. Stepwise regression using the REG procedure of SAS was used for the covariate adjustments for each of 15 variables, within race and gender by regressing on age, age ${ }^{2}$, age ${ }^{3}$ and field centers, and retaining only the significant terms. Age and field center effects were removed from the means and the variances, and standardized residuals were derived. A few outliers beyond \pm 4 standard deviations and greater than 1 standard deviation away from the next internal data point were eliminated. Final standardized residuals were utilized in the FA. FA is a multivariate statistical technique which explains variability of primary variables in terms of fewer unobserved (latent) variables named factors. The latent factors help to identify inter-correlations among primary variables. Two categories of factor analysis, with and without Varimax rotation, were performed, as previously described [7]. FA without rotation achieves the simplest factor structure, where the loading of a variable is maximum with one factor, associated with little contribution of that variable to other factors. In contrast, Varimax rotation identifies factors representing distinct clusters of interrelated variables. At least two risk variables in a latent factor were required with loadings of about 0.4 or greater. The factor loadings were essentially the correlation coefficients between each original variable and the latent factor. Factor loadings represent the contribution of each original variable to the latent factor. The original variables contribution into factors helped to label each latent factor. The squared factor loading represented the percentage of variance in the original variable associated with the latent factor. The sum of squared loadings per latent factor had to approach or exceed one and the maximum likelihood estimate model was required to be significant ( $\mathrm{p}$-value $<0.05$ ). Factor analysis applied on the 15 normally distributed traits, produced factor scores which finally were employed in linkage analyses.

\section{Linkage analysis}

The HyperGEN study genotyped 391 microsatellite markers at the National Heart, Lung, and Blood Institute Mammalian Genotyping Service (Marshfield, WI), of which 370 autosomal markers were used for this genome-wide linkage analysis. Software used to insure the marker' qual- ity control included ASPEX, GRR, GENEHUNTER and PEDCHECK [17-19]. The average inter-marker distance was about 10 centiMorgans (cM). The gender-averaged genetic distances were retrieved from the Marshfield human genetic linkage map. Ethnic-specific allele frequencies were calculated based on the random sample included in the HyperGEN study. Pedigrees were split in nuclear families for analyses. Multipoint identity by descent coefficients were estimated with MAPMAKER/ SIBS software, at $1 \mathrm{cM}$ contiguous distances [18]. Finally, a non-parametric variance component linkage analysis was performed via SEGPATH software [20]. The non-parametric (or model free) linkage method applied does not depend on the assumptions about the penetrance of the phenotype. On the other hand the marker locus model is applied by hypothesizing an additive effect of a QTL (g), a residual polygenic component $\left(G_{R}\right)$, and a residual nonfamilial variance component $(\mathrm{r})$. The null hypothesis of no linkage was tested by restricting the QTL heritability $\left(\mathrm{h}_{\mathrm{g}}^{2}\right)$ at the putative locus at $\mathrm{h}^{2} \mathrm{~g}=0$. The linkage test becomes a likelihood ratio of the alternative hypothesis against the null hypothesis, in every location throughout the genome where $\mathrm{h}^{2} \mathrm{~g}$ is estimated. This test turns out to be a $\chi^{2}$ with 1 degree of freedom [20].

\section{Results}

Table 1 for the African American's sample is a summary of LOD scores greater than 1.7 [see also the Additional files $1,2,3,4]$. Significant LOD scores greater than or close to 3 were found for "BP" domain in the African American sample in all data for FA with Varimax rotation (LOD score of $\sim 3.0$, with a peak at $67.8 \mathrm{cM}$ distance on chromosome 19). QTLs for "BMI-INS" factor domain were identified when DM subjects were excluded (LOD of 3.9, at 64.8 $\mathrm{cM}$ on chromosome 2, and LOD of 3.3 at $91.4 \mathrm{cM}$ on chromosome 12). For the same ethnicity, when FA with NO rotation was applied in all data, the above findings of chromosomes 2 and 19 replicated with LOD scores respectively of 2.8 and 2.7. For FA with NO rotation, when excluding DM participants two peaks for "BMI-INS" domain replicated above significant LOD scores (on chromosome 2, at $65.8 \mathrm{cM}$, LOD of 3.6, and on chromosome 12 , at $91.4 \mathrm{cM}, \mathrm{LOD}$ of 3.2).

Table 2 is a summary of QTL findings for the white sample [see also the Additional files 5, 6, 7, 8]. The "BP-LV wall thickness" factor, a combination of MetS-ECHO domains, result of FA with NO rotation when excluding DM subjects in whites, showed suggestive linkage with a maximum peak of 2.8 LOD score on chromosome 3 at 224.9 $\mathrm{cM}$, and a 2.6 LOD score on chromosome 20 at $2.1 \mathrm{cM}$. In addition, in the same ethnicity, for the "LV wall thickness" factor domain, two suggestive peaks were found; one on chromosome 3 at $114.3 \mathrm{cM}$, with LOD score of 2.7 for all data and NO rotation, and one on chromosome 16 at 
Table I: Major QTL findings per chromosome, LOD > 1.7 in African Americans

\begin{tabular}{|c|c|c|c|c|c|c|c|c|}
\hline No & Rotation & Excluding DM & Chromosome & $\begin{array}{l}\text { Sex-averaged distance } \\
\text { in cM, peak and } \\
\text { (surrounding markers) }\end{array}$ & Marker name & Dname & LOD* Score & Factor Domain \\
\hline 1 & NO & NO & 2 & $68.76(64.29-73.61)$ & $\begin{array}{l}\text { ATA4F03- } \\
\text { ATA27D04 }\end{array}$ & $\begin{array}{l}\text { D2SI356- } \\
\text { D2SI352 }\end{array}$ & 2.84 & BMI-INS \\
\hline 2 & & & 12 & $100.42(95.03-104.12)$ & $\begin{array}{l}\text { GATA63DI2- } \\
\text { GATA85A04 }\end{array}$ & $\begin{array}{l}\text { DI2SI064- } \\
\text { DI2SI300 }\end{array}$ & 1.98 & BMI-INS \\
\hline 3 & & & 19 & $68.84(68.08)$ & MDFI39 & DI9SI78 & 2.67 & $\mathrm{BP}$ \\
\hline 4 & & & 20 & $4.13(2.13)$ & AFM077XD3 & D20SIO3 & 1.78 & BMI-INS \\
\hline 5 & NO & YES & 2 & $49.76(47.97-55.5 \mathrm{I})$ & $\begin{array}{l}\text { GATA8F07- } \\
\text { GATA86E02 }\end{array}$ & D2S405-D2SI788 & 2.41 & BMI-INS \\
\hline 6 & & & 2 & $65.76(64.29-73.61)$ & $\begin{array}{l}\text { ATA4F03- } \\
\text { ATA27D04 }\end{array}$ & $\begin{array}{l}\text { D2SI356- } \\
\text { D2SI352 }\end{array}$ & 3.62 & BMI-INS \\
\hline 7 & & & 5 & II4 (I I4.75) & ATA4DIO & D5SI453 & 2.36 & BP \\
\hline 8 & & & 11 & 91.11 (85.48-100.82) & $\begin{array}{l}\text { GATA30G0I- } \\
\text { GATA28D0I }\end{array}$ & $\begin{array}{l}\text { DIIS2002- } \\
\text { DIIS2000 }\end{array}$ & 1.80 & BMI-INS \\
\hline 9 & & & 12 & $91.42(83.19-95.03)$ & $\begin{array}{l}\text { GATA26D02- } \\
\text { GATA63DI2 }\end{array}$ & $\begin{array}{l}\text { DI2SI052- } \\
\text { DI2SI064 }\end{array}$ & 3.22 & BMI-INS \\
\hline 10 & & & 18 & $54.84(54.40)$ & GATA64H04 & DI8S877 & 2.37 & BMI-INS \\
\hline 11 & & & 19 & $70.84(68.08-78.08)$ & MFDI39-MFD232 & $\begin{array}{l}\text { DI9SI78- } \\
\text { DI9S246 }\end{array}$ & 2.18 & $\mathrm{BP}$ \\
\hline 12 & VARt & NO & 5 & $36.00(36.25)$ & GATAI34B03 & D5S2845 & 2.42 & LIPIDS-INS \\
\hline 13 & & & 10 & $\begin{array}{l}153.32 \\
(148.17-165.27)\end{array}$ & $\begin{array}{l}\text { GGAA5DI0- } \\
\text { GGAA23C05 }\end{array}$ & $\begin{array}{l}\text { DIOSI2I3- } \\
\text { DIOSI248 }\end{array}$ & 1.87 & LIPIDS-INS \\
\hline 14 & & & 11 & $113.11(113.13)$ & GATA23606 & DIISI998 & 2.66 & LIPIDS-INS \\
\hline 15 & & & 19 & $67.84(68.08)$ & MFDI39 & DI9SI78 & 2.97 & $\mathrm{BP}$ \\
\hline 16 & VAR & YES & 2 & $64.76(64.29)$ & ATA4F03 & $\mathrm{D} 2 \mathrm{~S} 1356$ & 3.90 & BMI-INS \\
\hline 17 & & & 5 & $115.00(115.75)$ & ATA4DIO & D5SI453 & 2.02 & $\mathrm{BP}$ \\
\hline 18 & & & 12 & $91.42(83.19-95.03)$ & $\begin{array}{l}\text { GATA26D02- } \\
\text { GATA63DI2 }\end{array}$ & $\begin{array}{l}\text { DI2SI052- } \\
\text { DI2SI064 }\end{array}$ & 3.34 & BMI-INS \\
\hline 19 & & & 18 & $54.84(54.40)$ & GATA64H04 & DI8S877 & 2.02 & BMI-INS \\
\hline 20 & & & 19 & $68.84(68.08)$ & MFDI39 & DI9SI78 & 1.98 & $\mathrm{BP}$ \\
\hline
\end{tabular}

* Logarithm of odds; †Varimax rotation

$113.5 \mathrm{cM}$, with LOD score of 2.8 when performing Varimax rotation and excluding DM subjects.

\section{Discussion}

In the present study we examined a group of latent factors identified by performing factor analyses on 15 MetS or ECHO traits. The seven identified latent factors reduced the complexity of this large number of phenotypes. "Lipids-INS" factor was mainly contributed to by HLDC, TG and INS. "BMI-INS" was another factor identified from MetS domains. From the ECHO variables two latent factors were identified, "LV wall thickness" with main contributions from LVMI, PWT, RWT and MWS, and "LV geometry" with main contributors LVMI, LVID and RWT. "BP" factor, primarily a combination of SBP and DBP, was strongly evidenced in African Americans. However, when factor analysis with no rotation was applied in the whites, BP combined with "LV wall thickness" and "LV geometry" to form two new latent variables "BP-LV geometry" a com- bination of SBP, DBP, LVMI, PWT and LVID and "BP-LV dimension wall thickness" a combination of SBP, DBP, LVID, RWT and PP/SV. We look at these factors as MetS, ECHO, and a combination of MetS-ECHO latent factors. The presence of $\mathrm{BP}$ as a connector between MetS and $\mathrm{ECHO}$ is consistent with the increased risk of $\mathrm{CV}$ disease associated with hypertension. Chinali et al [21] found that abnormal LV geometry and function are related to the MetS, with increased BP being the MetS component most strongly associated with cardiac abnormalities [22]. Therefore, combined MetS-ECHO domains with BP contributions in the HyperGEN whites extend previous findings.

Two QTLs, one from MetS domains, and one from ECHO were prominent. The chromosome 12 QTL for the "BMIINS" factor was replicated across ethnic groups, although the LOD scores were larger in African Americans. Its location coincides with linkage reports at $12 \mathrm{q} 24.2$ for non- 
Table 2: Major QTL findings per chromosome, LOD > 1.7 in whites

\begin{tabular}{|c|c|c|c|c|c|c|c|c|}
\hline No & Rotation & Excluding DM & Chromosome & $\begin{array}{l}\text { Sex-averaged distance in } \\
\text { cM, peak and } \\
\text { (surrounding markers) }\end{array}$ & Marker name & Dname & LOD* Score & Factor Domain \\
\hline 1 & NO & NO & 3 & 114.32 (I 12.42) & GATAI $28 \mathrm{C} 02$ & D3S4529 & 2.71 & $\begin{array}{l}\text { LV WALL } \\
\text { THICKNESS }\end{array}$ \\
\hline 2 & & & 16 & $113.46(113.52)$ & AFM03IXA5 & DI6S402 & 1.79 & $\begin{array}{l}\text { LV WALL } \\
\text { THICKNESS }\end{array}$ \\
\hline 3 & & & 20 & $4.13(2.13)$ & AFM077XD3 & D20S103 & 1.82 & $\begin{array}{l}\text { BP-LV WALL } \\
\text { THICKNESS }\end{array}$ \\
\hline 4 & NO & YES & 3 & $201.32(201.14)$ & AFM059XA9 & $D 3 S 1262$ & 1.98 & BP-LV GEOMETRY \\
\hline 5 & & & 3 & 224.88 & AFM254VEI & D3SI3II & 2.79 & $\begin{array}{l}\text { BP-LV WALL } \\
\text { THICKNESS }\end{array}$ \\
\hline 6 & & & 12 & $98.42(95.03)$ & GATA63DI 2 & DI2SI064 & 2.32 & BMI-INS \\
\hline 7 & & & 15 & $78.30(82.84)$ & ATA28G05 & DI5S655 & 1.90 & $\begin{array}{l}\text { LV WALL } \\
\text { THICKNESS }\end{array}$ \\
\hline 8 & & & 16 & II3.46 (I I3.52) & AFM03IXA5 & DI6S402 & 2.61 & $\begin{array}{l}\text { LV WALL } \\
\text { THICKNESS }\end{array}$ \\
\hline 9 & & & 20 & 2.13 & AFM077XD3 & D20SI03 & 2.61 & $\begin{array}{l}\text { BP-LV WALL } \\
\text { THICKNESS }\end{array}$ \\
\hline 10 & VARt & NO & 3 & $5.32(5.54)$ & GATA22GI2 & D3S2387 & 2.01 & BMI-INS \\
\hline 11 & & & 3 & 114.32 (I 12.42) & GATAI $28 \mathrm{C} 02$ & D3S4529 & 2.18 & $\begin{array}{l}\text { LV WALL } \\
\text { THICKNESS }\end{array}$ \\
\hline 12 & & & 11 & I7.II (8.9) & ATA33B03 & DIIS2362 & 1.81 & BMI-INS \\
\hline 13 & & & 12 & $47.42(48.7)$ & ATA27A06 & DI2SI042 & 1.99 & LV GEOMETRY \\
\hline 14 & & & 16 & $113.46(113.52)$ & AFM03IXA5 & DI6S402 & 1.72 & $\begin{array}{l}\text { LV WALL } \\
\text { THICKNESS }\end{array}$ \\
\hline 15 & & & 21 & $19.99(24.73)$ & GATAI29DII & D2IS2052 & 1.81 & $\begin{array}{l}\text { LV WALL } \\
\text { THICKNESS }\end{array}$ \\
\hline 16 & VAR & YES & 3 & $218.32(215.84)$ & ATA22E0I & D3S24I8 & 2.26 & LV GEOMETRY \\
\hline 17 & & & 11 & $28.11(33.02)$ & ATA34E08 & UNKNOWN & 1.72 & BMI-INS \\
\hline 18 & & & 12 & $87.42(95.03)$ & GATA63DI 2 & DI2SI064 & 2.00 & BMI-INS \\
\hline 19 & & & 14 & $107.46(105.53)$ & GGAA2IGII & DI4S6I7 & 1.87 & $\mathrm{BP}$ \\
\hline 20 & & & 16 & $113.46(113.52)$ & AFM03IXA5 & DI6S402 & 2.81 & $\begin{array}{l}\text { LV WALL } \\
\text { THICKNESS }\end{array}$ \\
\hline
\end{tabular}

* Logarithm of odds; $\uparrow$ Varimax rotation

insulin dependent DM, rheumatoid arthritis, and multiple sclerosis $[23,24]$. In this area the $A C A C B$ gene located on 12q24.1 may be a candidate. This gene reported in murine studies, has been implicated in controlling mitochondrial fat oxidation and is considered a regulator of energy expenditure [25]. Although Wilson et al [26] reported a finding for fat mass in 12q24, their peak location is about 30-35 cM apart from our "BMI-INS" peak finding.

Of particular note are the results in the region around the marker AFM031XA5 (D16S402) at 16q24.2-q24.3 for the "LV wall thickness" in whites. This location marked by D16S402, has been found to be linked with cadherin 13 (CDH13) gene. CDH13, which is also called heart cadherin, is believed to be a calcium dependent mediator of cell-cell interaction in the heart and acts as negative regulator of neural cell growth. Joshi et al [27] claimed cad- herin may have multiple signaling functions in vascular remodeling and may protect endothelial cells from oxidative stress-induced apoptosis. The $\mathrm{CDH} 13$ gene is about $1.2 \mathrm{M}$ bp long, has 14 exons and encodes for a protein with 713 amino acids. This gene is most highly expressed in the heart. The AFM031XA5 marker represents a sequence between $81,851,181-81,851,356$ (bp), precisely in the non-coding $5^{\text {th }}$ intronic region. We hypothesize that the $C D H 13$ polymorphism, involved in calcium mediated cell-cell adhesion, can influence calcium deposition in the heart. Such a hypothesis is supported also by the Bella et al [12] study of valve calcification in the HyperGEN where a significant QTL (3.2 LOD score) was located on chromosome 16 relatively close to the above marker. In contrast, Mayosi et al [13] findings on chromosome 12 and 16 on LV mass do not overlap with our findings. We have a putative QTL located at $47 \mathrm{cM}$ (1.99 LOD score) on chromosome 12 for LV Geometry factor (with 
contributions of LVID (+), LVMI (+) and RWT (-)) in whites. Theirs, (2.19 LOD score) is located at $75 \mathrm{cM}$ based on the Marshfield genetic map. Our finding on chromosome 16 for LV wall thickness in whites (with contributions of LVID $(+)$, RWT $(+)$, and LVMI $(+))$ reaches a local maximum of $2.81 \mathrm{LOD}$ score at $113 \mathrm{cM}$. Theirs is located at the start of chromosome $16(18.07 \mathrm{cM}$ based on the Marshfield map), and reached a local maximum of 1.85 LOD score. Such differences may arise for several reasons; our study is ascertained for hypertension [14], larger in sample, our factor scores are composite traits compared to theirs for LV mass, to mention a few.

Other genetic linkage findings of interest included the MetS and ECHO factors, for "BP-LV wall thickness" and "BP-LV geometry" in whites (Table 2). For the "BP-LV geometry" factor a QTL on chromosome 3 at marker D3S1262 (201.3 cM) showed a LOD of 2.0 in the same location where an abdominal obesity MetS QTL was reported. [28] A QTL for "BP-LV wall thickness" factor with peak LOD score of 2.8 located on marker D3S1311 $(225 \mathrm{cM})$, in proximity to DLG1 gene which is reported to have a role in the epithelial differentiation and regulation of smooth muscle $[29,30]$. A LOD score of 2.3 was found for "LV geometry" after Varimax rotation, in a region that includes the FGF12 gene (fibroblast growth factor 12) which binds to the $\mathrm{C}$ terminus of the cardiac voltage-gated sodium channel $\mathrm{Na}(\mathrm{v}) 1.5$ and modulates the properties of the channel [31].

MetS related factors showed potentially important QTLs for African Americans. For example, "BMI-INS" factor showed highly significant results on 2p22-2p21 and on 12q24.2, as did the "BP" factor on 19q13.1 (Table 1). Chen et al [32] have previously reported strong linkage evidence in West Africans for percent body fat on chromosome 2 at $72.6 \mathrm{cM}$, relatively close to our 2p22-2p21 QTL finding. A possible candidate gene located at 2p21, close to the position of our linkage markers, is the LSL gene, which controls leptin serum levels. Candidate regions linking to our chromosome 19 BP QTL region have also been reported as for example by Bielinski et al. [33] for pulse pressure. Also Cooper et al [34] described an SBP QTL for Nigerians marked with D19S246 at $78.1 \mathrm{cM}$ (about $7 \mathrm{cM}$ distant from our finding) on the Marshfield map. Finally, in our study LOD scores increased when excluding DM subjects, which can be a reflection of the effect of genetic heterogeneity caused by diabetes.

Our new findings differ in several regards with the previous analysis of MetS in the HyperGEN study [9]. First, the majority of the selected risk factors differ. The previous study had 11 risk variables to characterize only MetS; while the current one includes MetS variables and variables that additionally embrace cardiac geometry and func- tion. Second, the sample sizes are not the same, and vary because of elimination due to missing values per variable and inability to include subjects from the $5^{\text {th }}$ HyperGEN center that did not participate in the ECHO study. Third, only $50-57 \%$ of the total original risk factors' variance was explained by the latent factors accepted in the model. Finally, the identified factors differ across studies in terms of the contribution of specific risk factors. Nevertheless when it comes to the "Lipids-INS" factor, (where a key contribution in African Americans was from HDLC, TG, and INS), the suggestive QTL found in the previous study on chromosome $11 \mathrm{q} 24$, is replicated in this study with a similar LOD score, but with a shift of the peak location (from $131.3 \mathrm{cM}$ to $113.1 \mathrm{cM}$ ). Combined traits analysis can discover QTL locations that affect more than one trait, i.e. with pleiotropic effects. The 11q23-24 human genome location is well known for a cluster of genes (APOA1, APOC3, APOA4, and APOA5), which effect the lipid levels as well as is associated with DM and heart disease [35]. In contrast, the use of two methodologies with and without Varimax rotation it might artificially increase the chances to obtain significant linkage results. Rao and $\mathrm{Gu}$ [36] showed that for a set of 400 genome wide markers, if the LOD score threshold is relaxed to $\sim 1.75$, one expects a tolerance of 1 false-positive per genome. It is expected that this threshold, used by us in reporting results, may achieve a better "balance" of the types of the statistical errors. However, in this study we emphasized LOD score results at the level of above 2.5 and 3. Also the arrangements of risk factors into MetS (and ECHO) factors lessen multiple comparison issues [37]. Another problem is the fact that we did not have a full evidence of replication about the QTLs in African-Americans and whites. Hirschhorn et al [38] have shown through simulations that a QTL explaining $20 \%$ of variance can produce strong signal in one linkage analysis, but it can be undetectable in another one, simply for the reason of sampling variation. An additional possibility is that a common causal genetic mutation in one population might be rare in another population.

We expected not only that factor scores to provide an opportunity to detect pleiotropic gene effects. In addition, when traits closely related such as SBP and DBP form a separate factor they provide an increased power to detect putative QTLs compared with single trait analysis. For example, analyzing separately SBP and DBP produced weak LOD scores in the peak found on chromosome 19. When analyzed with the factor scores in African Americans we found a LOD score of 2.67, 2.18, 2.97, and 1.98 depending on the rotation method used and including or excluding T2D subjects. Nevertheless we do not know if the BP factor findings are true or type I error results. Consequently, further elucidation of the precise location of the causative polymorphisms of the identified linkage 
peaks is being processed with an abundant number of SNPs.

\section{Conclusion}

This study is the first genome-wide linkage study that utilizes factors scores derived simultaneously both from domains of MetS and of cardiac geometric and functionality phenotypes. They provide some insight into the genetic relationship underlying MetS and cardiovascular traits. Refined SNPs genotyping with a million SNPs platform will soon enhance the ability to discover causative genes of the cardiac- and MetS related QTLs on chromosome 16q24.2-q24.3 that coincided with linkage within cadherin 13 gene and the one on 12q24 which replicated in both ethnicities.

\section{Abbreviations}

ARD: aortic root diameter; BP: blood pressure; BMI: body mass index; $\mathrm{cM}$ : centiMorgan; CV: cardiovascular disease; DBP: medication adjusted blood pressure; DM: diabetes mellitus; ECHO: echocardiography; FA: factor analysis; GLUC: fasting glucose; HDLC: high-density lipoprotein cholesterol; HR: heart rate; HyperGEN: Hypertension Genetic Epidemiology Network Study; INS: fasting insulin; LOD: lod score; LV: left ventricular; LVH: left ventricular hypertrophy; LVID: diastolic LV internal dimension; LVMI: LV mass indexed to height ${ }^{2.7}$; MetS: metabolic syndrome; MWS: LV midwall shortening; PP/SV: arterial stiffness defined by pulse pressure/stroke volume; PWT: posterior wall thickness; QTL: quantitative trait loci; RWT: relative wall thickness; SBP: medication-adjusted systolic blood pressure; SNPs: single nucleotide polymorphisms; TG: fasting triglycerides.

\section{Competing interests}

The authors declare that they have no competing interests.

\section{Authors' contributions}

All authors contributed equally.

\section{Additional material}

\section{Additional file 1}

Figure 1. Linkage analysis of factors in African Americans, all data, no rotation. The graph represents the linkage analysis results.

Click here for file

[http://www.biomedcentral.com/content/supplementary/1471-

2350-9-103-S1.pdf]

\section{Additional file 2}

Figure 2. Linkage analysis of factors in African Americans, excluding $D M$, no rotation. The graph represents the linkage analysis results. Click here for file

[http://www.biomedcentral.com/content/supplementary/14712350-9-103-S2.pdf]

\section{Additional file 3}

Figure 3. Linkage analysis of factors in African Americans, all data, Varimax rotation. The graph represents the linkage analysis results.

Click here for file

[http://www.biomedcentral.com/content/supplementary/14712350-9-103-S3.pdf]

\section{Additional file 4}

Figure 4. Linkage analysis of factors in African Americans, excluding $D M$, Varimax rotation. The graph represents the linkage analysis results. Click here for file

[http://www.biomedcentral.com/content/supplementary/1471-

2350-9-103-S4.pdf]

\section{Additional file 5}

Figure 5. Linkage analysis of factors, whites all data, no rotation. The graph represents the linkage analysis results.

Click here for file

[http://www.biomedcentral.com/content/supplementary/14712350-9-103-S5.pdf]

\section{Additional file 6}

Figure 6. Linkage analysis of factors, whites excluding DM, no rotation. The graph represents the linkage analysis results.

Click here for file

[http://www.biomedcentral.com/content/supplementary/14712350-9-103-S6.pdf]

\section{Additional file 7}

Figure 7. Linkage analysis of factors, whites all data, Varimax rotation. The graph represents the linkage analysis results.

Click here for file

[http://www.biomedcentral.com/content/supplementary/1471-

2350-9-103-S7.pdf]

\section{Additional file 8}

Figure 8. Linkage analysis of factors, whites excluding DM, Varimax rotation. The graph represents the linkage analysis results.

Click here for file

[http://www.biomedcentral.com/content/supplementary/14712350-9-103-S8.pdf]

\section{Acknowledgements \\ Primary Centers and Investigators of HyperGEN}

\section{University of Utah}

(Network Coordinating Center, Field Center, and Molecular Genetics Lab)Steven C. Hunt, PhD (Network Director and Field Center PI); Mark F. Leppert, PhD (Molecular Genetics PI); Jean-Marc Lalouel, MD, DSc; Robert B. Weiss, PhD; Roger R. Williams, MD (late); Janet Hood

Univ. of Alabama at Birmingham

(Field Center)

Cora E. Lewis, MD, MSPH (PI); Albert Oberman, MD, MPH; Donna Arnett, $\mathrm{PhD}$; Phillip Johnson; Christie Oden. 


\section{Boston University}

(Field Center)

Richard H. Myers, PhD (PI); R. Curtis Ellison, MD; Yuqing Zhang, MD; Jemma B. Wilk, DSc; Luc Djouss?, MD, DSc; Jason M. Laramie; Greta Lee Splansky, MS.

\section{University of Minnesota}

(Field Center and Biochemistry Lab)

James S. Pankow, PhD (Field Center PI); Michael B. Miller, PhD; Michael Li, PhD; John H. Eckfeldt, MD, PhD; Anthony a. Killeen, MD, PhD; Catherine Leiendecker-Foster, MS; Jean Bucksa; Greg Rynders

\section{University of North Carolina}

(Field Center)

Kari E. North, PhD (PI); Barry I. Freedman, MD; Gerardo Heiss, MD

Washington University

(Data Coordinating Center)

DC Rao, PhD (PI); Charles Gu, PhD; Treva Rice, PhD; Aldi T. Kraja, DSc, PhD; Gang Shi, PhD; Yun Ju Sung, PhD; Karen L. Schwander, MS; Stephen Mandel; Shamika Ketkar; Matthew Brown; Michael A. Province, PhD; Ingrid Borecki, PhD; Derek Morgan

\section{Weil Cornell Medical College}

(Echo Reading Center)

RB Devereux, MD; Giovanni de Simone, MD, Jonathan N. Bella, MD

National Heart, Lung, \& Blood Institute

Cashell Jaquish, PhD; Dina Paltoo, PhD.

This hypertension network is funded by cooperative agreements (UI0) with NHLBI: HL5447I, HL54472, HL54473, HL54495, HL54496, HL54497, HL54509, HL545 I 5.

\section{References}

I. Levy D, Garrison RJ, Savage DD, Kannel WB, Castelli WP: Prognostic implications of echocardiographically determined left ventricular mass in the Framingham Heart Study. N Engl J Med 1990, 322:156|-1566.

2. Burchfiel CM, Skelton TN, Andrew ME, Garrison RJ, Arnett DK, Jones DW, Taylor HA Jr: Metabolic syndrome and echocardiographic left ventricular mass in blacks: the Atherosclerosis Risk in Communities (ARIC) Study. Circulation 2005, I | 2:819-827.

3. Ferrara LA, Cardoni O, Mancini M, Zanchetti A: Metabolic syndrome and left ventricular hypertrophy in a general population. Results from the Gubbio Study. J Hum Hypertens 2007, 21:795-80I.

4. Mule G, Nardi E, Cottone S, Cusimano P, Palermo A, Incalcaterra F, Giandalia ME, Cerasola G: Impact of the metabolic syndrome on total arterial compliance in essential hypertension patients. J Cardiometab Syndr 2007, 2:84-90.

5. Masugata $H$, Senda S, Goda F, Yoshihara Y, Yoshikawa K, Fujita N, Daikuhara $H$, Nakamura $H$, Taoka T, Kohno M: Left ventricular diastolic dysfunction as assessed by echocardiography in metabolic syndrome. Hypertens Res 2006, 29:897-903.
6. Sciarretta S, Ferrucci A, Ciavarella GM, De Paolis $P$, Venturelli V, Tocci G, De Biase L, Rubattu S, Volpe M: Markers of inflammation and fibrosis are related to cardiovascular damage in hypertensive patients with metabolic syndrome. Am J Hypertens 2007, 20:784-79I.

7. Huang P, Kraja AT, Tang W, Hunt SC, North K, Lewis CE, Deverux RB, de Simone G, Arnett DK, Rice T, Rao DC: Factor Relationships of Metabolic Syndrome and Echocardiographic Phenotypes in the HyperGEN Study. J Hypertens 2008, 26(7): $1360-1366$.

8. Teran-Garcia M, Bouchard C: Genetics of the metabolic syndrome. Appl Physiol Nutr Metab 2007, 32:89-I I 4.

9. Kraja AT, Hunt SC, Pankow JS, Myers RH, Heiss G, Lewis CE, Rao DC, Province MA: Quantitative trait loci for metabolic syndrome in the Hypertension Genetic Epidemiology Network study. Obes Res 2005, 13:1885-1890.

10. Arnett DK, Devereux RB, Kitzman D, Oberman A, Hopkins P, Atwood L, Dewan A, Rao DC: Hypertension Genetic Epidemiology Network Study Group. Linkage of left ventricular contractility to chromosome II in humans: The HyperGEN Study. Hypertension 200I, 38:767-772.

II. Tang W, Arnett DK, Devereux RB, Atwood LD, Kitzman DW, Rao DC: Linkage of left ventricular early diastolic peak filling velocity to chromosome 5 in hypertensive African Americans: the HyperGEN echocardiography study. Am J Hypertens 2002, I5:62I-627.

12. Bella JN, Tang W, Kraja A, Rao DC, Hunt SC, Miller MB, Palmieri V, Roman MJ, Kitzman DW, Oberman A, Devereux RB, Arnett DK: Genome-wide linkage mapping for valve calcification susceptibility loci in hypertensive sibships: the Hypertension Genetic Epidemiology Network Study. Hypertension 2007, 49:453-460.

13. Mayosi BM, Avery PJ, Farrall M, Keavney B, Watkins H: Genomewide linkage analysis of electrocardiographic and echocardiographic left ventricular hypertrophy in families with hypertension. Eur Heart J 2008, 29:525-530.

14. Williams RR, Rao DC, Ellison RC, Arnett DK, Heiss G, Oberman A, Eckfeldt JH, Leppert MF, Province MA, Mockrin SC, Hunt SC: NHLBI Family Blood Pressure Program: methodology and recruitment in the HyperGEN network. Ann Epidemiol 2000, 10:389-400.

15. Devereux RB, Roman MJ: Evaluation of cardiac function and vascular structure and function by echocardiography and other noninvasive techniques. In Hypertension: Pathophysiology, Diagnosis and Management 2nd edition. Edited by: Laragh JH, Brenner BM. Raven Press Ltd., New York, USA; 1995.

16. Wu J, Kraja AT, Oberman A, Lewis CE, Ellison RC, Arnett DK, Heiss G, Lalouel JM, Turner ST, Hunt SC, Province MA, Rao DC: A summary of the effects of antihypertensive medications on measured blood pressure. Am J Hypertens 2005, I 8:935-942.

17. Abecasis GR, Cherny SS, Cookson WOC, Cardon LR: GRR: graphical representation of relationship errors. Bioinformatics 200I, 17:742-743.

18. Kruglyak L, Daly MJ, Reeve-Daly MP, Lander ES: Parametric and nonparametric linkage analysis: a unified multipoint approach. Am J Hum Genet 1996, 58:1347-1363.

19. O'Connell J, Weeks DE: Pedcheck: a program for identification of genotype incompatibilities in linkage analysis. Am J Hum Genet 1998, 63:259-266.

20. Province MA, Rice TK, Borecki IB, Gu C, Kraja A, Rao DC: Multivariate and multilocus variance components method, based on structural relationships to assess quantitative trait linkage via SEGPATH. Genet Epidemiol 2003, 24(2): I28-138.

21. Chinali M, Devereux RB, Howard BV, Roman MJ, Bella JN, Liu JE, Resnick HE, Lee ET, Best LG, de Simone G: Comparison of cardiac structure and function in American Indians with and without the metabolic syndrome (the Strong Heart Study). Am J Cardiol 2004, 93:40-44.

22. Ferrara LA, Guida L, Ferrara F, De Luca G, Staiano L, Celentano A, Mancini M: Cardiac structure and function and arterial circulation in hypertensive patients with and without metabolic syndrome. J Hum Hypertens 2007, 2 1:729-735.

23. Bektas A, Suprenant ME, Wogan LT, Plengvidhya N, Rich SS, Warram $\mathrm{JH}$, Krolewski AS, Doria A: Evidence of a novel type 2 diabetes locus $50 \mathrm{cM}$ centromeric to NIDDM2 on chromosome I 2q. Diabetes 1999, 48:2246-225I. 
24. Jawaheer D, Seldin MF, Amos Cl, Chen WV, Shigeta R, Monteiro J, Kern M, Criswell LA, Albani S, Nelson JL, Clegg DO, Pope R, Schroeder HW Jr, Bridges SL Jr, Pisetsky DS, Ward R, Kastner DL, Wilder RL, Pincus T, Callahan LF, Flemming $\mathrm{D}$, Wener $\mathrm{MH}$, Gregersen PK: A genomewide screen in multiplex rheumatoid arthritis families suggests genetic overlap with other autoimmune diseases. Am J Hum Genet 200I, 68:927-936.

25. Choi CS, Savage DB, Abu-Elheiga L, Liu ZX, Kim S, Kulkarni A, Distefano A, Hwang YJ, Reznick RM, Codella R, Zhang D, Cline GW, Wakil SJ, Shulman Gl: Continuous fat oxidation in acetyl-CoA carboxylase $\mathbf{2}$ knockout mice increases total energy expenditure, reduces fat mass, and improves insulin sensitivity. Proc Natl Acad Sci USA 2007, 104: 16480-16485.

26. Wilson SG, Adma G, Landown M, Reneland R, Braun A, Andrew T, Surdulescu GL, Norberg M, Dudbridge F, Reed PW, Sambrook P, Kleyn PW, Spector TD: Linkage and potential association of obesity-related phenotypes with two genes on chromosome I 2q24 in a female dizygous twin cohort. Eur J Hum Genet 2006, 1 4:340-348.

27. Joshi MB, Philippova M, Ivanov D, Allenspach R, Erne P, Resink TJ: Tcadherin protects endothelial cells from oxidative stressinduced apoptosis. FASEB J 2005, 19:1737-1739.

28. Kissebah AH, Sonnenberg GE, Myklebust J, Goldstein M, Broman K, James RG, Marks JA, Krakower GR, Jacob HJ, Weber J, Martin L, Blangero J, Comuzzie AG: Quantitative trait loci on chromosomes 3 and 17 influence phenotypes of the metabolic syndrome. Proc Natl Acad Sci USA 2000, 97: I4478-। 4483.

29. Roberts S, Calautti E, Vanderweil S, Nguyen HO, Foley A, Baden HP, Viel A: Changes in localization of human discs large (hDlg) during keratinocyte differentiation is associated with expression of alternatively spliced hDlg variants. Exp Cell Res 2007 313:252I-2530.

30. Mahoney ZX, Sammut B, Xavier RJ, Cunningham J, Go G, Brim KL, Stappenbeck TS, Miner JH, Swat W: Discs-large homolog I regulates smooth muscle orientation in the mouse ureter. Proc Natl Acad Sci USA 2006, 1 03:19872-19877.

31. Liu CJ, Dib-Haij SD, Renganathan M, Cummins TR, Waxman SG: Modulation of the cardiac sodium channel Navl.5 by fibroblast growth factor homologous factor IB. J Biol Chem 2003, 278: $1029-1036$

32. Chen G, Adeyemo AA, Johnson T, Zhou J, Amoah A, Owusu S, Acheampong J, Agyenim-Boateng K, Eghan BA, Oli J, Okafor G, Abbiyesuku F, Dunston GM, Chen Y, Collins F, Rotimi C: A genome-wide scan for quantitative trait loci linked to obesity phenotypes among West Africans. Int J Obes (Lond) 2005, 29:255-259.

33. Bielinski SJ, Lynch Al, Miller MB, Weder A, Cooper R, Oberman A, Chen YD, Turner ST, Fornage M, Province M, Arnett DK: Genomewide linkage analysis for loci affecting pulse pressure: the Family Blood Pressure Program. Hypertension 2005, 46:1286-1293.

34. Cooper RS, Luke A, Zhu X, Kan D, Adeyemo A, Rotimi C, Bouzekri N, Ward R: Genome scan among Nigerians linking blood pressure to chromosomes 2, 3, and 19. Hypertension 2002, 40:629-633.

35. Singh P, Singh M, Gaur S, Kaur T: The ApoAl-CIII-AIV gene cluster and its relation to lipid levels in type 2 diabetes mellitus and coronary heart disease: determination of a novel susceptible haplotype. Diab Vasc Dis Res 2007, 4: I24-129.

36. Rao DC, Gu C: False positives and false negatives in genome scans. Adv Genet 200I, 42:487-498.

37. Arya R, Blangero J, Williams K, Almasy L, Dyer TD, Leach RJ, O'Connell $P$, Stern MP, Duggirala R: Factors of insulin resistance syndrome-related phenotypes are linked to genetic locations on chromosomes $\mathbf{6}$ and $\mathbf{7}$ in nondiabetic Mexican-Americans. Diabetes 2002, 5 I:84I-847.

38. Hirschhorn JN, Lindgren CM, Daly MJ, Kirby A, Schaffner SF, Burtt NP, Altshuler D, Parker A, Rioux JD, Platko J, Gaudet D, Hudson T], Groop LC, Lander ES: Genomewide linkage analysis of stature in multiple populations reveals several regions with evidence of linkage to adult height. Am J Hum Genet 200I, 69: I06-I I6.

\section{Pre-publication history}

The pre-publication history for this paper can be accessed here: http://www.biomedcentral.com/1471-2350/9/103/pre pub
Publish with Bio Med Central and every scientist can read your work free of charge

"BioMed Central will be the most significant development for disseminating the results of biomedical research in our lifetime. "

Sir Paul Nurse, Cancer Research UK

Your research papers will be:

- available free of charge to the entire biomedical community

- peer reviewed and published immediately upon acceptance

- cited in PubMed and archived on PubMed Central

- yours - you keep the copyright

Submit your manuscript here:

http://www.biomedcentral.com/info/publishing_adv.asp
BioMedcentral 